\title{
Surfaces
}

\section{J. Hillis Miller's "Humanistic Discourse and the Others" Roundtable Discussion}

\section{Hazard Adams, Ernst Behler, Hendrik Birus, Jacques Derrida, Wolfgang Iser, Murray Krieger, Hillis Miller, Ludwig Pfeiffer, Bill Readings, Ching-hsien Wang et Pauline $\mathrm{Yu}$}

Volume 6, 1996

DISCUSSIONS DU PREMIER CONGRÈS INTERNATIONAL SUR LE DISCOURS HUMANISTE

DISCUSSIONS FROM THE FIRST INTERNATIONAL CONFERENCE ON HUMANISTIC DISCOURSE

URI : https://id.erudit.org/iderudit/1064840ar

DOI : https://doi.org/10.7202/1064840ar

Aller au sommaire du numéro

Éditeur(s)

Les Presses de l’Université de Montréal

ISSN

1188-2492 (imprimé)

1200-5320 (numérique)

Découvrir la revue

Citer ce document

Adams, H., Behler, E., Birus, H., Derrida, J., Iser, W., Krieger, M., Miller, H., Pfeiffer, L., Readings, B., Wang, C.-h. \& Yu, P. (1996). J. Hillis Miller's

"Humanistic Discourse and the Others": Roundtable Discussion. Surfaces, 6.

https://doi.org/10.7202/1064840ar
Résumé de l'article

Ces discussions autour du texte de J. Hillis Miller, «Humanistic Discourse and the Others ", ont eu lieu en avril 1994, dans le cadre du premier Congrès sur le Discours Humaniste. Les communications de cette première réunion du Congrès ont été publiées dans le volume 4 de Surfaces (1994).
Copyright (C) Hazard Adams, Ernst Behler, Hendrik Birus, Jacques Derrida, Wolfgang Iser, Murray Krieger, Hillis Miller, Ludwig Pfeiffer, Bill Readings, Ching-hsien Wang et Pauline $\mathrm{Yu}, 1996$

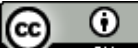

Ce document est protégé par la loi sur le droit d'auteur. L'utilisation des services d'Érudit (y compris la reproduction) est assujettie à sa politique d'utilisation que vous pouvez consulter en ligne.

https://apropos.erudit.org/fr/usagers/politique-dutilisation/ 
$\underline{\text { Surfaces }}$

\title{
J. Hillis Miller's \\ "Humanistic Discourse and the Others" \\ Roundtable Discussion
}

\author{
Hazard Adams \\ Ernst Behler \\ Hendrick Birus \\ Jacques Derrida \\ Wolfgang Iser \\ Murray Krieger \\ Hillis Miller \\ Ludwig Pfeiffer \\ Bill Readings \\ Ching-hsien Wang \\ Pauline $\mathrm{Yu}$
}

Surfaces Vol. VI.103 (v.1.0A - 10/08/1996) - ISSN:

1188-2492

Copyright for texts published in Surfaces remains the property of authors. However, any further publication should be accompanied by an acknowledgement of Surfaces as the place of initial publication.

\begin{abstract}
This roundtable discussion of "Humanistic Discourse and the Others", J. Hillis Miller's contribution to the first International Conference for Humanistic Discourses, was held in April, 1994. The papers of this first meeting of the ICHD have been published in volume 4 of Surfaces (1994).
\end{abstract}

\section{RÉSUMÉ}

Ces discussions autour du texte de J. Hillis Miller, "Humanistic Discourse and the Others", ont eu lieu en avril 1994, dans le cadre du 
premier Congrès sur le Discours Humaniste. Les communications de cette première réunion du Congrès ont été publiées dans le volume 4 de Surfaces (1994).

Miller : I'm anxious about the time, since I want to make some points that extend my paper a little, so I'm not going to summarize it. I think you've all read it. There are three sections to the paper. The first part raises some questions about the words "humanistic" and "discourse." The second part develops the idea or nonconcept of the other and attempts to identify that. The third section is more parochial. It talks about the problems of English departments in the United States at this point, and the curricular problems, but it has a more general implication. In this country, English departments are the central humanistic disciplinary site where our values and traditions and so on have traditionally been promulgated.

The three additional points I would like to make now are: First just to say a word more about the notion of the other and my interest in it - it's my current research project. I have a little statement here that's probably more elegant than anything I could make up. I certainly wouldn't deny in any way that any act of reading or writing, like any ethical act of commitment (like a decision, or choice, or witnessing, or refusal, or saying "no") is constrained by enormously complex overdetermined social and historical contexts. It's not a matter of denying that there is such a context. That context, I think one would have to remember, is unique to each given act. That is to say, you can't establish it for such and such an epoch, postmodernism, and have done with it, say that's postmodernism; everybody in that period is going to be subject to that. You have to do this contextual work, in a way, over again each time. And certainly, that context includes, national, gender, racial, and class, as well as linguistic specificities. I must say that I've been a little uncomfortable with this group having only one woman. That defines our work here; it's all men with the exception of Pauline. And it's worth taking note of that. It doesn't really correspond, the group that we've chosen, for reasons that are perfectly explicable and not at all sinister, to, let's say, the makeup of my Department of English and Comparative Literature, or there would be a lot more women. And a few more, one would hope, a few more so-called minorities. Nevertheless, in spite of all of that that I've 
said, I hold (and I'm trying to show) that each act of reading or writing, like ethical acts in general (I would include reading and writing under that category), is a performative new start. This new start, in however a minute, tiny way, makes history. That is to say, in the sense that history is changed by that act. That means that the notion of performative language that I'm using here (I called it a performative) must be understood outside the classical conception of speech acts as determined in their efficacy by institutional codes, rules, and expectations that still remain firmly in place after the speech act has done its work. You have the marriage ceremony; it acts in a certain way to marry a couple of people, and the marriage ceremony is still there. Nothing has really happened to change the surrounding context. The new start I'm defining deflects the course history otherwise would have taken. It changes then, however minutely (and it's often very minute), the context it enters. It changes that context. It does this in response to a demand made on the one who performs the act by what I'm calling the other of language, the other of the other person, and the other of the social institutions within which the act in question is formed. Here's a place where I need that what I call the nonconcept of the other. This other is an alterity that cannot be logically understood by being turned to some version of the same. That is to say, it's not a same other. If you say, well, I don't mean this book; I mean the other one. The word "other" as I am using it doesn't mean that. It's the other as wholly other, really other. This other may not be defined either in terms of transcendence (one must resist the obvious danger in this concept of the other, the almost irresistible temptation to return it to some notion of a Platonic or Christian notion of some kind of transcendent place, some other place) or in terms of imminence (that is to say, of something that's inside in some way). Those are two theological concepts: the theological pair, transcendence and imminence. If I can be autobiographical for a moment... those were the concepts that governed my two books after the Dickens book, those two books on nineteenth and twentieth century literature, The Disappearance of God and Poets of Reality. These were entirely controlled by the notion of either transcendence or imminence. In the Victorian period was The Disappearance of God (God wasn't exactly dis-believed in, it's just that God wasn't here), and in the twentieth century there was a diffuse imminence. I now find those notions very problematic, including the zeitgeist notion that I had then. It's the part of my work that most embarrasses me. But I've long, for a long time been haunted by this idea of an altogether other. It's a sort of glimpse out of the corner 
of the eye, so to speak. That may be the thing that has most concerned me. That's what I'm really working on now, in my work on Henry James and on Proust.

Second point. I think we need to spend a little more time than we have so far in recognizing that our... American society, at any rate, and I think world society, is in the midst of a radical transformation that's moving it further and further away from traditional literary culture. So that we have to think, what's the purpose? That's what I meant by saying, why would one want to do this now? I've just received an application from Sam Weber to teach an NEH summer seminar. He says that these transformations, the shift from verbal to audio-visual, an effect of the rise of the electronic media and in particular television and video, are far-reaching, radical, and widespread. He says, I think correctly, that they're made even more complex by the fact that they're ongoing. We're in the middle of this change, and you can't really see which way it's going. Proust is very good on this. A person who lives through an historical moment never knows it until later on. We're in the middle of something that we have some vague idea of, but only in retrospect would we know. Weber goes on to say something shrewd about this, and that is that it's normally by our colleagues in, let's say, film studies and in other such areas, it's normally thought of as a categorical break and used as justification for no longer being interested in literary theory or linguistic theory at all. You say, because film is so different we don't have to read these people anymore. So the question how such transformations are understood - how they're to be approached, interpreted, analyzed, is, as Weber says, of the utmost importance and urgency. The other alternative would be to recognize that the notion of sign and signifier might be extended to include other forms of inscriptional models. After all, as Weber observed, we call it photo-graph-y and cinemato-graph-y. The notion of some kind of graph, graphing is there. And it's certainly there in genetic theory, and in the notion we've been hearing about the Internet this morning and the digitizing of images, and so on.

Final, third point. And I'll tell you this very quickly. This is what would really take a long time. One of the things that worries me these days is the question, why study literature in this circumstance? What's the point of it any longer, if we live in an age in which our students don't read anymore, in which their culture is defined by telecommunications of various trends? I'm not at all condescending to the sophistication and complexity of television and cinema culture, but nonetheless it's 
different. All the time you spend watching Rosanne on television (which is a very interesting program) you're not reading Shakespeare. You're not even reading Thomas Hardy or Charles Dickens. So I'm worried about that. And I have an answer which I'll propose from Proust. Proust is full of marvelous passages. My reading of Proust is that he's the great fractal author. You all know what fractals are. Here's a picture of one. Fractals have the peculiarity of being self-similar. Whatever level of smallness you take is a repetition of the larger... but a repetition with a difference. So fractal theory is part of chaos theory. My argument would be that the large scale of Proust is repeated in what's called a self-similar way in very small parts - for example, in figures of speech. And here's an example where that is made public, and where my willingness to read Proust and study him is justified. Proust says, "Well, I used to believe, when I heard Germany or Bulgaria or Greece say things, and protest their pacific intentions, I used to give credence to these statements. But since life with Albertine and Françoise, I've become accustomed to suspect them in that - that is, the kings of these countries' thoughts and projects which they did not disclose, that is, kept secret... secrets. I now let no pronouncement, however specious, of William II, or Ferdinand of Bulgaria, or Constantine of Greece deceive my instinct and prevent it from divining what each one of them was plotting." And he goes on to say, "Anybody who is incapable of comprehending the mystery, the reactions, the laws of these smaller lives..." And for me this would be Albertine's story primarily, namely Marcel's comic mistake about Albertine, his assumption that he can know whether or not she's lesbian. So he's confusing (it would take a long time to explain this) a cognitive situation with a performative, unknowable one. But he goes frantically to get evidence. He gets people to witness Albertine in the baths, and so on, and none of this proves what he wants proved. Whether Marcel Proust knew this, whether Marcel the narrator or Marcel the character (there are three people here) knew this or not is another question. So what he's saying is, anybody who's incapable of understanding, let's say, the story of Marcel and Albertine, "the mysteries, the reactions, the laws of these smaller lives, will make only futile pronouncements when he talks about struggles between nations." So if you want to know about politics and history, read Proust. It makes me feel so much better that I can, with a clear conscience, spend, I think, the rest of my life now, trying to understand Proust - it's a big book. I've never found a page, by the way in spite of the authority of the standard translation, where you don't have to go back to the French and always find 
differences. And often the kind of shocking ones where the translators came to a line, they didn't see the point of it, and they just leave it out. And that happens quite frequently, even though this is a very authoritative translation. That's all I have to say.

Iser : Just a quick question: to what extent are your readings of otherness, as you have put it in your paper, fractals? Is it that self-sameness would appear to be strangeness, or foreignness, or alterity, if it were not sameness with difference? That would be one consequence of what you have been saying with regard to Proust.

Miller : Yes, yes, okay.

Iser : So we would have to read your listing of the various descriptions of otherness in that light? Basically, you do not postulate a stance outside these various types of otherness, which would invalidate what you're doing. Consequently, the fractals might be a way of indicating otherness, which then would pose the question of how to assess that difference if it's the self-sameness with difference? There's one possibility: If we take a pairing like 'theme and horizon,' as advanced by Schütz, we have the advantage of being situated inside the very many types of otherness and make them mutually refract one another. The relationship between 'theme and horizon' allows to see the reverse side of any otherness, because if something is thematic and the other type of otherness forms the horizon for looking at it, it is bound to change the moment you move on to the next one. Such an alternation of 'theme and horizon' allows you to travel inside the various types of otherness, relieves you of establishing a stance outside of them, and prevents you from lapsing into a descriptive taxonomy. Instead, we are able to spot the difference in the sameness as we are now given to perceive something that was initially not in view.

Furthermore, why has otherness become such an important issue? Is it another of those hypostatizations that we have been witnessing since the 'sixties, when society was elevated into an all-encompassing blanket concept, which, when on the wane, was substituted by language? After the essentialization of language, caused by the linguistic turn, we have now 'otherness' as the beall, and end-all that is invoked as guidance for all kinds of intellectual activities. What does the 'new start' mean that you are advocating? Is it an exploration of otherness in terms of total difference, ungraspable alterity, or incommensurability? Coming to grips with such an issue 
we would have to avoid the Scylla and Charybdis of drowning out otherness into a taxonomy and of predicating what we might consider it to be. Again, the pairing of 'theme and horizon' appears to me a framework for exploring the issue under consideration as we can stay inside and nevertheless be able to manage what we are confronted with.

Miller : Right. That's a very interesting characteristic... I don't know quite how to put it... Iserian theorizing. You're so good at it and it's so compelling. I'd say two things about it only, very briefly. One is that I don't think the encounter with the other is a theme. Therefore it's in principle unthematizable, so that that would be the problem with using your very attractive way of making sense out of this. How does one order it? For me, precisely the danger is to conceptualize it and to make it routine, so you say, here's another example of it. So the only way in which I could defend encountering the other would be to say that in the acts of reading Henry James, let's say, or Proust, or somebody else, it becomes an event... I encounter it in a different way each time. I'm very anxious about imposing some kind of conceptual scheme about this which I then come to the reading of Proust with. I think that's a general problem in reading, but you do your best with it. So the movement back and forth from theory to reading is tricky. The final thing would be to say, I think that historically it goes back a good bit further. I was teaching a course on this this year. I began with an old essay by Levinas, which goes back I think to 1962, called "La trace de l'autre." Levinas, in any serious attempt to find a history of this, a modern history, would certainly go way before the 'nineties back to the Greeks and the Bible. It's awkward to speak in Derrida's presence of Derrida, but the term "other" in Derrida's work is not new. It goes way way back to something that people have not traced very much. The citation I make from that interview dates from the early 'eighties, when he's already speaking of this as something that he had fixed in his mind. There's a complicated history through Jacques' work of "the other." So I don't think you can say that the use of "the other" as a key term in cultural studies arises with the development of cultural studies. It's precisely that definition of the other that I claim is caught within the return to sameness. You speak of the other as the other of such and such a culture. For example, in David Lloyd's work on Africa.

Iser : I didn't mean it as a criticism, but obviously there is a horizon as a backdrop for delineating the specificity of otherness. 
Miller : Well, I hope that when people read my work it will become very influential and seem timely!

Iser : Well, whenever you thematize one manifestation of the other it is bound to turn into a backdrop for other manifestations. That strikes me as the underlying pattern of what you are saying, at least in my understanding. Manifestations may function as contextual constraints.

Miller : I don't think so... I don't think it works that way.

Behler : I also would like to pursue the theme of the other, although the other two points are of equal interest to me. If I understand you correctly, you picked a whole range of forms of otherness in terms of what confronts us in strangeness, othernesses which can be accommodated, which can be adopted intellectually, emotionally, or appropriated in one way or the other. However, I also find a form of otherness in your paper also, that is an alterity in completion, that is wholly other, that can never be accommodated, that can never be appropriated. You describe it on page ten, and you also talk about it in your remarks this morning, and that is this fear that is almost, you say, "from beyond the world" - it assumes almost metaphysical features. I have the impression that this is an otherness that is not from the outside, that is not a partner of dialogue, that is not a partner at all, but more the inner self, otherness from within. Is my interpretation correct?

Miller : No, not exclusively. At the top of page ten, I speak of this as perhaps a feature of my own inner self, but also, as for Marcel [in] Proust, something he encounters in another person. And that's rather different. And that again is different from what I find in Oedipus. Or what I find in Aristotle's Poetics and Rhetoric - the curious role of the irrational in Aristotle's formulations. Nothing irrational should be included - for example, no murders on the stage. Because there is a kind of relationship in both the Poetics and Rhetoric to a notion of an irrational other which I don't think you could define as the inner self or as the encounter with another person. To call it death is to give it another name. You might say that those names, for me, are another form of performative catachresis. One way that language works as a speech act is to say, "I name this, I call this death." But to say that is to... Well, I didn't call it Madness, but you might. In other words, in one way, the name doesn't matter, because no name has authority 
technically speaking, it's a catachresis. That is to say, you move a name in from somewhere else to cover a kind of blank in cognition. In another way it makes a lot of difference what name you move in. When Stevens writes a great elegy like "The Owl in the Sarcophagus," where the name that's given to the other is "death," that's different, very different from Marcel giving it the name of the impossibility of ever knowing whether or not Albertine is a lesbian. It seems like something you ought to be able to get factual information about... Did she perform lesbian, Gomorrahn acts? That's all he wants to know, or that's what he says he wants to know. Proust's point cannot be known. Once he doesn't love her anymore, then it can be known, like the way you can know history if you're outside it. But while he's in love he can't know. And that parallel with history is made repeatedly.

Readings : I just wanted to come back to this question of otherness and what I understood Hillis and Wolfgang to be saying to each other. If I understand what you're saying here, there's a fundamental distinction between something like singularity and something like exemplarity, that the other you're talking about would be non-exemplary, would be singular, and that's the extent to which there is a radical new start involved in the performative and ethical act of reading, whereas the other in cultural studies would be precisely thematic, because it would be an example, the other would be an example of something and would be susceptible to allegorization, and then through allegorization to cognition. And I think that I like the word singularity because it gets me out of that transcendence/imminence bind, the way I often do that. And it seems to me that there I want to ask you to say a bit more about your third question, because it seems to me that if we accept - and I do, I'm entirely convinced by your argument for the singularity of reading and writing as ethical acts, as performances - - then we have to say, all of the claims that have traditionally been made for the humanities or the human sciences, and for the benefits of reading, rest upon a certain exemplarity. The institution exists to lend to the act of reading its exemplarity and its diffusion. That's what, you know, the institution does. One reads... You read Proust in an exemplary way and your students then understand the example. Then you say at the end, to know politics and history, read Proust, and I think you're right. And I think it's very important. I think it's an extremely difficult challenge for us to imagine an nonexemplary discourse of the humanities. Because it's clear to me that what you're saying when you read this passage about Albertine is not "This is an example of 
how to find out about politics." So I want to push you to sort of sketch a little more what this kind of singular account of the act of reading would mean in institutional terms, in terms of the kinds of claims we could then make for the humanities.

Miller : Very difficult. Mostly what I said in my paper was negative in the sense of saying that the old assumptions of exemplarity no longer work. I was building on a very interesting paper by a colleague in American Studies here, Brooke Thomas (an unpublished paper) on the crisis of representation. He speaks of a problem in the curriculum, the loss of confidence in, in Bill's terms, the exemplarity of particular works. And I was certainly brought up in that old tradition. With a clear conscience, I could read Proust or Dickens or Thomas Hardy as representative of the culture they belong to, and let's say of Victorian or twentieth-century French literature. I mentioned Auerbach's Mimesis as a classic case of the old paradigm, because it so wonderfully persuades you that out of one passage from To the Lighthouse he can give you all of modernism, that all the rest of it is going to be like that. It's belief in synecdoche, in part for whole. If you no longer believe in that, the question then would be, how would you organize a curriculum that made any kind of sense? And I think my problem with the development of cultural studies now is that I think it's still caught in the old paradigm. It makes the same kind of claims. And if they're serious about wanting to change the university, they're not really doing that. They're just developing another discipline which is subject to the same set of presuppositions. I spoke at the very end of my paper (and this would be the only answer that I could probably give you now, Bill) about a university of dissensus, that is to say, one which recognized that singularity you spoke of and in some way institutionalized it. Because I think we've always had and still have the assumption that even if you expand the disciplines so that we have media studies (and they're now developing here a visual studies program - - it's an obvious thing to do - which would combine art history and film, and so on, into one subject), that can be somehow assimilated into a whole, a totality that would have some kind of coherence. If you cease to believe in that, the question would be, how would you then construct a curriculum? The only answer I can give is that each of us then is responsible for teaching from year to year things that are not exemplary, but singular. That is to say, if I get interested in Proust, I can't really defend that anymore in the old way. We know what's wrong with Proust - he's a white male, a canonical author. The only thing that we'd have going for him is 
that he's a homosexual, so I can defend him on those grounds... The same with Henry James. So I can say, well they're both white males, but they're both homosexuals, so that it's a part of queer theory that I'm doing. But I think the point is that there's no justification any longer beyond the choice that I make out of the encounter that I've had with these works in which I want to tell other people what has happened to me when I read these books. And it's marvelous that I have an institutional opportunity to do that. It's a thing I think we forget that we have in Western universities - the privilege, with some limitations of course, to teach anything we want. Because if I decided here next year that I wanted to teach Beowulf, I don't think they could stop me. They would be a little puzzled by my change on that. And certainly we have not been stopped in English departments from teaching Hegel, Levinas - I don't have any authority to teach Levinas. Then why do I teach him? Because I've read this, and I found something there, and I want to tell people about it. This is taking place already. This is a free, dissensive university. I teach only what I want.

Derrida : Yes, but your students finally make the decision. If they don't come at all (which isn't the case, I'm sure), then you'll stop teaching it. Finally, you have to convince, performatively, the students of your choice.

Miller : And that's difficult sometimes.

Derrida : You have to convince performatively, that is, produce a situation where...

Behler : But we no longer have faculty meetings in the sense of agreeing on a curriculum that has a certain coherence in education.

Derrida : I'm sure that in some situations, academic situations, the decisions are made collectively in a meeting, but once someone has the authority to make decisions as Hillis does.

Iser : There's no authority to singularity, is there?

Derrida : Well, Hillis has the authority, first to say, well, to say to his colleagues, "I want to teach Proust or..."

Miller : Or Beowulf.

Derrida : ... and they won't object. If, to the extent that the students don't object, it is a matter of authority, 
authority - not simply the institutional authority, but the authority that you have built.

Miller : I should say (just to follow that for just a second), on the other hand, it's not quite so simple, at least in my department here, in English and Comparative Literature, which is a community of dissensus if there ever was one. Nevertheless, we have department meetings in which we decide on revisions of the curriculum, and this is voted on. A group of people in American Studies redefine American literature now as multilingual, including our Chicana person and people who teach Native American stuff, and so on - an American literature which is not just New England, but really is multilingual. The Comparative Literature people are a second group. The third group is made up of those in English literature. And these are three very different groups, though they overlap. But those English people are now redefining the English program in a much more conservative and traditional way, throwing out all the stuff that's not English, saying, our students... these students, fifty percent of whom are non-caucasian, must read Samuel Johnson, and so on. I'm not saying that shouldn't be done, but there is a good example, as you say, of authority and power. In this university, the largest by far undergraduate major in literature is in the English Department, a more or less traditional English major. So it's a battleground, but the one that to some degree is still fought in department meetings.

Krieger : First I want to say that I couldn't agree more with this whole notion of the new start in every act of reading and in every act of writing, and so on. And the phrase you don't have in the paper, but which you often use, is that "literature makes something happen." This must be central to any claims for the humanities we can make. And I agree with Bill's reading of that too. I want to get back a little to some of what Wolfgang was pressing to begin with, and that is how to keep otherness, as you use it, a non-concept In the course of the paper, "other" does a number of different jobs for you. First, the one that seems soundest, in a way, is the ground, or rather the ungrounded ground for the paper: the deconstructionist notion of "the other of language," which you quote from Jacques. "The other of language," on page five, and then strongly reinforced (with differences, perhaps) but reinforced by your discussion of Paul de Man and his notion of the "otherness within language," "suspension of meaning" (this is on page 7), the non-monological way in which language works. Let me call it linguistic otherness, or verbal otherness, the 
inevitable, unavoidable, thing that language does as it works. Second, returning to the passage that Ernst mentioned on page 10, the encountering of the inner self with a kind of otherness as well, as the self "may be 'encountered"... as wholly other"; and in the rest of that paragraph otherness is to some extent (forgive me) being thematized into what, for lack of a better word, let me call an existential concept of other. And third, beyond that, in a number of places in the paper, (see, for example, page 6), I find "racial, class, gendered, national other." You cite Lyotard's notion of heterogeneity. This third "other" seems to be, for lack of a better word, let's call it a political other. And I'm wondering, as "other" functions on these three different levels (maybe that's what Wolfgang meant when he suggested that the sort of fractals were replicating one another in different levels and in different ways), I'm wondering, or rather worrying a little about whether having "other" operating in these ways, whether the word is the same word? Is it really the same word in every case? Is the linguistic verbal "other," the other that shows itself in the very way in which language, the words, work, always forcing us to worry, if we read well enough about what is not there, the translation that insists upon telling us why it's untranslatable, and so on? Is that "other," mutatis mutandis, really the same? In what way can we use the word "other" here as we use the word "other" when we refer to our racial, gendered, ethnic others? The "other" there seems to have more substance, if you will, more - I almost said the word "reality" - but in a way, yes, almost that for us. And when I read the bottom of page 10 "Perhaps the wholly other may be a racial, national, class, or gender other that is truly other" - then the word "truly" makes me very very nervous, metaphysically, or essentialistically, worried about what is a non-truly other if something can be truly other? Aren't we awfully close to a concept of the other? And doesn't the other, as it functions on these several levels - undifferentiatedly, if you will (that is, the linguistic other, the existential other, or the political other) - doesn't it seem suspiciously like a universal?

I just have one other small question, which is not related to this at all. And this is perhaps a theoretical question, perhaps a tactical - maybe a political - question. And that is, when, toward the bottom of page twelve, in talking about choosing between Moby Dick and Uncle Tom's Cabin, you claim that the choice of one rather than the other is a "result of a motivated and unjustifiable choice." The word "unjustifiable" is a strong one. Let's hold that for a moment. Then in the very next sentence, "Nor can there any longer be a recourse to some 
standard of intrinsic superiority allowing us to say that Moby Dick is a better work than Uncle Tom's Cabin, since that standard too is the result of ideological bias." Of course my instinct is to say, is that not giving too much away? But in the context of the paper I want to ask, is this last statement not an ideological statement? And your "is" in it is a very strong, very strong verb there: "since that standard too is the result of an ideological bias." It's a conclusion you could have reached only by having a certain kind of ideological critique of ideology. But as I say, that would be the theoretical question. The political question is, is there no conceivable way of saying Moby Dick is more worth talking about as text than Uncle Tom's Cabin, except an ideological way.

Miller : I think we've had it on that. I really do. Because it can be easily demonstrated that any set of criteria that define one as better than another is open to that kind of criticism, just as...

Krieger : What about the performative one that when I read Moby Dick, things are happening to me that... of a totally different order from what...

Miller : That's your own fault. Good for you.

Krieger : That's my fault.

Miller : It's your fault. Because you belong to a certain class and race and all the rest of it. The trouble with ideology critique is that it doesn't free you from ideology.

Krieger : But that kills your "new start" argument. If you believe that, then the new start argument is out the window.

Miller : I don't see why. I don't see how that has anything at all to do with it.

Krieger : Because every work is a reconfirmation of the ideology you have going into it. In that case...

Miller : No, no, no. I said ideology... no, no. I said that any attempt to establish cognitive principles for saying Moby Dick... It has nothing at all to do with the performative new start. It has to do with the choice of books to read. That wouldn't keep me from choosing to prefer to teach Moby Dick to Uncle Tom's Cabin. All I was saying was that I can't justify that a priori by saying that it's absolutely a better work. 
Krieger : I'm not saying absolutely. I'm saying, is there nothing between saying it absolutely and not being able to say it at all?

Miller : No, no, I don't think there is.

Krieger : Okay.

Miller : Do you want to go on on that before we go back to the other? Bill, did you have something to say?

Readings : I would just intervene there with the canon and choice. I think that the only thing I have difficulty with is when I think you conflate England and America a little too quickly. You say it's very difficult for English people to read this, but the ethnic grounds for the canon in England or France, England or Germany, is different from that in America, and this is why the canon debate is a specifically American debate, because the canon is the object of republican choice ultimately. The Norton Anthology is like American law. We can imagine that it has no ethnic content to it whatsoever; it is simply the republican will of the rational and democratic choice of an ethnic tradition by a people that actually is not vitally linked to that tradition. Whereas of course, there is no choice about Shakespeare in England or about Milton in England because the functioning of the notion of the ethnic tradition is very different.

Krieger : As a matter of fact, we could add to that, Bill, that I think someone like Stanley Fish would probably be more offended by this sentence than others of us might be, because for Stanley, it is probably justifiable, given communities of interpretation and the rest.

Readings : Exactly.

Krieger : ... which does not necessarily make it ideological.

Readings : But Stanley believes in a different kind of choice than Hillis. When you have a problem with Hillis on that statement of that ideological bias and the question of whether the new start argument goes out the window, you have to distinguish again between two...

Krieger : I was saying, one is theoretical and one's political. 
Readings : But that's the weight of Hillis's use of the word "ethical," as I understand it, his choice to teach Beowulf next month because that's what interests him, in some sense his demand that that is a singular act of choice and a new start for Beowulf, that there is a performative quality to his choice, is very distinct. That's ethical choice, as opposed to the claim that the choice is in some way authoritative, exemplary, or representative. So that the representative status element isn't the only one that you can make for the canon in America. I mean, that's the distinction. John Guillory in his book Cultural Capital, goes through that quite well. I mean, you can make a time in America that the canon does not have to be representative. It simply has to be the choice of the institution.

Miller : Legislated.

Readings : Legislated, yes. So those two are available, whereas in Britain or in Germany, and in France despite its supposedly republican status, there is a representative necessity that's different. But I think that it involves completely rethinking... It seems to me that Hillis's argument involves completely rethinking the question of what it means to choose one text over another.

Krieger : Oh, I agree, absolutely.

Readings : And it involves thinking absolutely without alibis, and that's why I would call it ethically responsible, that you have no reason to give that will absolve you from political responsibility for having chosen to teach Moby Dick this month instead of Uncle Tom's Cabin. And indeed it is a discut-able... discussable question.

Someone can raise their hand and say, "Why are we reading this and not that?" And in some sense, you're not allowing yourself the statement, in advance, either "Because that is not part of the canon, because that is not good literature, because that is not recognized by the institution." Ultimately you're saying, "Because I say so." And that's... to return to what Jacques said about how you have to convince the students. But you have to take responsibility for that act of convincing the students about your reading, rather than invoking some alibi. And I think that's a very ethical stance. It's also an enormous amount of work for any teacher, it seems to me, practically. It's not a time-saving response.

Krieger : It ought to be looked upon as totally arbitrary, of course, and authoritative, in the sense that people 
want to take Hillis Miller, and anything Hillis talks about, thinking, I want to be there. And so the choice...

Derrida : In that case, it couldn't mean simply, well, because Hillis Miller has such and such a reputation, because implicitly, when he makes his choice, implicitly for him and implicitly for the students, there is a possible hidden political discourse justifying the choice. Even if you don't thematize everything, you could... I think Hillis could, we could explain why the choice of Moby Dick is better, not only literarily, but politically better. Given some time, I could show you that it's not simply a matter of taste or a matter of literary preference. I could try and demonstrate that it is politically more efficient if you leave me the possibility of teaching Moby Dick the way I want to teach it.

Krieger : Jacques, if that's the case, then my choice of a Moby Dick might not be the result of my having elitist, defensive ways of protecting the proper American tradition of the academy.

Derrida : In that case, which means that convincing the students means that we use not simply our supposed authority, but supposed capacity that we have in principle demonstrated to lead the students to read this and that in such a way that they are convinced that it's politically more important to read Moby Dick than $x$ or $y$. In a certain context. I wouldn't say, in any context I would prefer Moby Dick. In some contexts. And then I would like to be free to evaluate the context. In some contexts, perhaps I would say, well, Tom's Uncle Cabin would be more appropriate. It depends on the...

Krieger : If you're talking about attitudes toward slavery in the history of nineteenth century America, sure.

Derrida : Or read together, both.

Miller : That's what's now done.

Iser : That raises the problem. To what extent the singularity of a decision become exemplary?

Derrida : This leads me to the point I wanted to make about this problem of singularity. It would be my first point.

Krieger : I hope to go back to the other. 
Derrida : But of course. Obviously, each time I make such a decision to put Moby Dick on my agenda, on the one hand, I imply that I try to demonstrate that it is an exemplary choice. But I can't give general reasons for that. It is to insert the singularity within a network of general motives, general good reasons. That is, when I teach, I try to be exemplary. But not without totally erasing some singularity: Well, this is my history. I'm signing when I teach. I try to be exemplary, but at some point I do what I'm the only one... That's what I can do. I cannot teach just anything, for instance. I have no justification for that. I can't do that. You have in front of you a man who has this age, who was born in this place, and I don't want to erase this singularity from my signature. So there is the negotiation between pure and simple singularity and exemplarity.

Iser : Negotiation is...

Derrida : Negotiation, yes. Of course. That's what we're doing all the time, all the time. To come back to this point, the point you made about otherness, thematization, and horizon: Hillis told you that the other is unthematizable, the other in its pure alterity. It's precisely what is unthematizable. Although you may thematize, you thematize always the unthematizable. But it's unthematizable. I agree with a number of points made by Hillis. I agree with this, but I would add (and this is more difficult to show) that finally, if there is such a thing as pure alterity, pure otherness, it's not only unthematizable. It is something which undermines the opposition between theme and horizon. The alterity of the other is something for which you have no horizon, that is, cannot be... The horizon structure the way it functions in Phenomenology, in Heidegger. You need the concept of horizon to have something on this background of the horizon. And I would claim that the other appears without appearing as such, never appears as such. It appears without appearing as such when you cannot anticipate it, him, or her anymore, when there is no horizon. It comes from no horizon. Not only you cannot predict the other as such, you cannot anticipate the other, you cannot foresee the other... Where the other happens, so to speak, there is no horizon. No theme, no horizon. So this couple of concepts is precisely what is put into question by the possibility of the other coming, I would say, the event, the singular event of the other as such. If... (And of course, I say if there is, if there is such an other - I say "if" because this otherness cannot become the object of a cognitive statement, of a determining, judgmental statement. The relationship to 
it is only a possibility, an act of faith, so to speak, something which belongs to the determining community of judgment.) If there is ("if" there is) such an other, then there is no theme, no horizon. And then the question arises whether (and this question is for Hillis) whether the fractal structure, this repetition with a difference inside, is, let's say, capable of this... has something to do, is a good representation of this other I just ask. Is the self-similarity within the fractal structure, is it commensurable with this otherness?

Krieger : One problem, Jacques, with the fractal metaphor in this case, is that there are certain determining characteristics in the fractal, despite chaos theory... The chaos theory operates within a whole series of determinisms that insist on the absolute.

Krieger : But at the same time it insists on the absolute homology among the levels, which is almost a structuralism, though always with an open end.

Derrida : Nevertheless, it's I agree a necessary question. But at the same time, I understand that in this mise-en-abyme - fractal, mise-en-abyme - of course there is some, let's say, fragile but radical otherness, within the same, within the same. It's there, it's there. So... I don't know what to do with this.

Miller : It's different from the mise en abyme. And then my first answer would be to say no, that the fractal image is no more than a name like these other names, and a dangerous one. For one thing, fractals are not language. You're talking about language and the structure of language...

Derrida : But you're using that as a model for...

Miller : As a model. It is... However, as you know, the structure is the product of, if not language, of a mathematical formula, and what I...

Derrida : And also crystal...

Yu : Crystalline structure.

Derrida : Crystal structure.

Miller : right. Well, and other structures which are around us all the time, like trees... I find fractals fascinating, but I agree with you. I'm not quite sure whether they fit my non-concept of the other. They do a shoreline. The Maine coast is a fractal coast, because the outline of the whole state is repeated on smaller and 
smaller and smaller structures, but repeated with differences. This book (by a Dutch mathematician, Hans Lauwerier) specifies the difference between fractals that are absolutely regular, where the smaller stage is just like the larger ones, and other fractals which have an element of unpredictability. That is to say, the next layer down is going to be something like the one above, but you can't tell ahead of time in what way it will deviate. And that makes it different, really, from the mise en abyme, where the next repetition is just smaller.

Nevertheless, I'm uneasy about that parallel too. Like all analogies it falsifies. I have used another scientific parallel which has no more authority than the fractal one, and that's the black hole. What's interesting about the black hole is that it gives me what you just very elegantly formulated. You say, "the other, if there is such a thing." Because it's not possible for it to be the object of cognition, you can't ever say there is such a thing. All you can say is, "if there is such a thing." And that's also true of black holes. Over and over again they say, well, the existence of black hole hasn't been proved. We don't know whether there are black holes or not. Why? Because you can have no direct evidence for them. Nothing comes back of a black hole. You can only infer their existence.

Krieger : But one crucial difference has made me worry about the black hole analogy: the concept of the other is so powerful and has swept us up into being concerned about it, because we meet it every day. It is a fact of experience. I mean, insofar as there's a fact, it is a fact of experience. As we conceive our experience, we know there is otherness there, whereas black holes are totally speculative.

Yu : It's a necessity of theory.

Krieger : It's a necessity of theory and not of experience, yes.

Yu : I think theory demands it. I mean, the theory demands that the black hole exist.

Miller : Yes, well, it's not just the theory. It's the observed celestial phenomena, observed just as much as anything else. But I agree that both of these images, both the fractal, which I didn't put in the paper, and the black hole...

Iser : Well, in Gergory Bateson's words, the black hole - or the black box as he prefers to call it - reflects a point at which we are "to stop trying to explain things." 
Miller : The parallel here is the claim that in spite of the fact that one has to say the other, if it exists, that doesn't mean, as Murray is saying, that one doesn't need the hypothesis of such a thing, if only to get on with the work of reason.

Derrida : ... If there is this danger of homogeneity within the fractal structure, repetition of same, sameness, then what would you do with the crypt? That is, of course there is an insertion of something into something, inscription, within the fractal. Is it the same structure as the incrypting of the dead other, with all the work of mourning? So the absolute other adds death, and of course the problem of death is at the center of your paper. And the work of mourning, is it the same inclusion, same structure of inclusion in both cases, or should we distinguish, and by what, between the two structures of inclusion? If indeed the singularity of the other is what we agreed it is a moment ago, then it might be difficult to push the analogy too far, between the fractal and the incrypting. This leads me to another point. Of course Murray reminded us a moment ago that we use the term "other" every day, and especially when we speak, whether in cultural studies or in political discourse, the "other" as a nation for example. I think that the fact that we refer to this absolute other different from these determined others... doesn't prevent us from trying to analyze what's going on in several of them, what you would call exegetic frames. In such a moment, we determine this concept of otherness. In such and such a way it becomes predominant, and so on and so forth. But these are the backgrounds, so to speak, groundless background of this reference to this absolute other. But we could do the two things at the same time. One doesn't exclude the other: that we pay attention to the absolute other and to the historical determinations of the discourses on the other in the academy, in the political space, etc.

Now, my second point, Hillis - and I agree with you about the reason why we study literature, we should continue to study literature. And I would argue that there are a number of good reasons, good political reasons, to continue. First, the machinery, all the media technology of today, is something absolutely, utterly primitive, however sophisticated it is, absolutely primitive compared to literary works. So if we want to teach the complexity of the semiotic systems - that's one reason among others - if we want to teach the maximum complexity of the speech act or techno-communication, 
teletechno-communication, we know that the good models, the best models are in literature. We can show that. That's one reason. The other reason would be directly political. That is, I could justify that teaching reading first, teaching literature is politically justifiable, that reading Beowulf or Proust is politically... I won't say politically correct, but it's politically useful - depending on the way we teach it, depending on the way you read it, and so. But there is no reason why it shouldn't be politically efficient. One reason among others, other political reasons, is the fact that it teaches the memory of language. And if, on the side of, let's say, ethnic nation minorities, we or they want to cultivate the memory of the non-artificial language, the memory of the natural language, then literature is the best place to identify and to cultivate and to grow this memory. Of course, there is as performativity of this act.

Now a last point, which has to do with your paper, the written paper, not the presentation you gave, the oral presentation you gave. At the end of the paper, when you advocate an institutionalization of the dissensus in the university, I am afraid you're too optimistic about it. Because at some point, you... That's Gerry Graff's main point. That is, we should institutionalize the conflict, the dissensus. And I'm not sure it's possible, first, and I'm not sure it's desirable then. Because if the dissensus is clearly a dissensus, a dissensus between different interpretations within writings, singularities, then to institutionalize the dissensus is a way of reducing the sharpness of the discussions. And I'm sure the people that you've tried to gather in your agreement, all these people would have probably some trouble agreeing with one another.

Miller : Yes, they would.

Derrida : Let's have a space where we can argue and where the conversation continues. We won't kill one another... We'll speak. We'll continue to speak. And I must confess, although my agreement with Habermas is very limited, I agree with him that that's what we are doing. And the discussion we have on the discussion, on the disagreement, is part of what's going on.

Krieger : But if we institutionalize the entire university to do this, then we're in danger of creating what Lyotard would call a master narrative.

Derrida : You cannot, you cannot, let's say, have rules, have a constitution for that. You cannot have a charter 
for that. But apparently that's what happened. But equally it affects what happens. We'll have to say, well, in fact there is a conflict of forces, and we, as polite discussants, polite advocators, we represent a certain force, a certain power of the field, and for us or for determined interests, we behave that way, we are politely discussing. But we know that it's only a small part of the structure, that it's impossible to imagine an institutionalization of the dissensus. But it's in public, purely in public. But that's what democracy's supposed to be - they disagree, they vote and, it continues. So it's a question about which concept of democracy.

Iser : Hillis, would you allow that two more people just make a statement before you reply, or would you want to reply?

Miller : Nope. I don't need to reply.

Iser : And I'll refrain, Jacques, from replying to you with regard to theme and horizon.

Miller : I still have to say something about something Murray said a long time ago. But go ahead, Ludwig.

Pfeiffer : I find myself in a slightly strange situation though, because I can't follow, I think I can't follow the urge to posit that absolutely other, but I still don't see where the urge comes from. It cannot be a conceptual urge, because I think conceptually we are more or less into Wolfgang Iser's direction. We have to be within the theme/horizon semantics. That would also explain the facts of experience Murray's talking about. If we talk about the experience of the other as a fact of experience, we are talking within the theme/horizon thing anyway, as soon as we translate that into experience. So you say, Hillis, it's a non-concept. Yes, but where does the urge come from to posit it there? That's basically my question, maybe to both of you.

Miller : - From the other.

Pfeiffer : Which other? Not the totally other. Would it be the same for you, or not the same, if we say, instead of the absolutely other, something provisionally or maybe forever unknowable, and leave it at that? So that would make the notion of the totally other not indifferent...

Behler : ... the radical other from one's own drive for knowledge. That's where you come to the other.

Pfeiffer : Yes, that is the second point I'm coming to. Is it possible, as a kind of suspicion, is it possible that the 
radical quality of that notion of the absolute other derives from our experience, maybe, which may have been sponsored or fueled by literature and philosophy, the illusion, namely, that we have known too much, and therefore now, since it turns out that we cannot know that much, that suddenly now we posit the... something like the absolutely other.

Krieger : Can I return this to language for a moment? I find, and I think for many of us this will be the case, we find the experience of the other when we read, when we read and we read carefully enough, and all the language before us starts dancing and doing the things it's not supposed to do...

Derrida : I agree, but not only when we read.

Krieger : No, no, no. But I'm not saying only when we read. I'm saying that since you've convinced me that texts are not representations of reality, when we read we are forced to see, as we read, as when Hillis reads Proust and sees...

Miller : That was going to be my answer to you. You're right about heterogeneity in my list of "others." That was intentional, because I wanted to show that you can by no means, out of these theorists, put together some kind of coherent notion of the other. They all differ from one another.

Derrida : The other is the interruption.

Miller : But that interruption can occur... In reading is one way. It's our professional way, but only one way. And my novels give me a report of the other... it's a verbal report, but what I'm being told about here doesn't depend on language except in some secondary kind of way. So I don't think...

Krieger : But is the verbal "other" of Paul de Man, in the quotes you have from him, the same word?

Miller : That would be an example of this diversity I was talking about, because de Man would have been very uneasy with my terminology. In the same way, I think, Jacques would not use the term "material" in a way that would be at all like de Man. So if we say these are really important notions in these two theorists, it's a place not where they come together, but where to some degree they diverge. And as you say, the end point in a really serious reading of de Man is to try to figure out what he meant by "the materiality of language." That's a very funny use of the word "materiality." And I was, for my 
own purposes, saying, he wouldn't have liked calling it "the other." The fact that he was interested primarily in language doesn't mean that I have to be interested exclusively in language. That's an important way...

Krieger : It's just that the way in which the self/other of language functions with the non-concept element there, and the element of untranslatability, of the mise en abyme that doesn't let you reach to the core because there always is that other - I'm saying that you will have to demonstrate that that way of operation is analogous to, or similar to the kind of operation you're describing in the set-up of the relationships within cultural identities. And the reason I say that is that I do believe the power of the other in your paper is derived essentially from the way in which language functions in a way that doesn't permit essentializing. I'm afraid when you get to the cultural identity issue, or the gender identity or any other identity issue, and the confrontation of otherness, it's not so easy to keep the other from becoming identified conceptually.

Miller : But I think there's a contrary danger in language. That is to say that with the reading of poetry there's an equally dangerous mystification in which, in spite of everything, we speak of this other as somehow something that's linguistic, not as the other of language at all. So it helps, I think, to make sure that language is not the only form of this interruption, and to insist on that.

Krieger : And you would say the word "other" is appropriately used as the same word in these several instances.

Miller : Sure, sure, sure. Marcel didn't need language to have problems with Albertine. That was a bodily, to some degree non-linguistic... If the other is really other, it's really other... it's so much other than language that to link it essentially to language would be a mystification.

Krieger : And "the truly other," what's the force of "truly"?

Miller : Jacques, a few minutes ago, said something I think is very useful and helpful here. He said that the notion of the absolute other does not in any way preclude other forms of otherness which are historical, et cetera, et cetera. And I would go beyond what he said to say that they always involve one another, that you can't really have one without the other. So that when I say there are two notions of otherness, one in which is 
some kind of return to the same, and the other notion of the absolutely other, I think they always, in any particular case, involve one another, that you can't really have one without the other, and that the danger is that one will always turn into the other. So that they're not the normal kind of "either/or," but related in a different kind of way.

Pfeiffer : Let me pursue this uninformed guess I was making. In spite of what you said, Murray, that reading literature makes, let's say, the world dance before your eyes, or whatever, and Jacques' sense of the high complexity which we don't get in any other media, one might still say... it's not an objection, but one might still describe this as a kind of control or, relatively speaking, intelligible complexity we are dealing there with, even in the most complicated puns or whatever...

Krieger : "Intelligible" is a hard word there. Do you mean "intelligible" that we can read it, or "intelligible" as knowable by the mind?

Derrida : ... less intelligible than the technology, media technology.

Pfeiffer : But still I think we are somehow under the spell of the way Hegel described the workings of language of making you believe that you see what's going on. But literature is the only art which creates the illusion that it can treat everything, and that it can present everything in some kind of palatable (to get away from "intelligible") shape. But it is possible, if we do not see, let's say, the situation with the other media in that contrast, complex and primitive - of course it sometimes is true - yet, if we do not see it exclusively in that way, we may come up with, instead of the difference between the totally other and appropriation, we may come up with, not the frame or theme or horizon, but, let's say, levels of knowability, levels of intelligibility, levels of nonsense, levels of indifference, we would always stay on both sides, inside the alternative appropriation and otherness. And in terms of cultural experience, I'm not quite sure. I mean, this may be just an illusion too, but you come to a foreign culture, and on the one hand it seems totally other. On the other hand, you may have experience of the opposite kind too. What do you make of it then? So that the notion of the totally other seems to me to be provisional too, and one would have to see in each case where the urge for it comes from - not the conceptual legitimacy, but the urge for it. 
Miller : I think the urge, the real urge, is from the other, at least for me, and I would think historically.

Pfeiffer : What you mentioned in your paper.

Miller : Yes. That's it. Because it's not too pleasant. It upsets things. Another (as I say, I'm a humble teacher of works of literature) another very striking example is the wonderful novel by Henry James called The Wings of the Dove. This is a novel about someone who makes an agreement with his fiancée to pretend to make love to a woman who's very wealthy, who's dying, Milly Theale. His guilt is the result of a quasi-performative acts... He simply doesn't say to her, "I'm only pretending to court you." The result of this is that after her death (death is fundamental in this novel; it's a novel about death), she wills him all of her money, which he refuses to accept. Nevertheless, he is in love with her, with her memory. She's done the one thing that will separate him from his fiancée, namely to leave the money and to leave a letter which he doesn't even have to read, so it doesn't depend on language. The letter is burned. So it's a case where the destructive effect of this otherness is dramatized in a wonderful novel. That novel is very hard to face, very hard to accept... And I would say that most of the interpretations of it attempt to escape recognizing what it's really about. And there's no doubt that a tremendous amount of literary criticism (including, I'm sure, my own, lots of my own) is precisely an attempt to refuse, cover over, explain away, make intelligible, so that you don't have to worry about it anymore.

Derrida : This is a machinery where, let's say, the undecidability (to go quickly) is far more complex that any technology yet devised. Of course, we are, I am totally incompetent, don't know how to make a computer work. Okay. Nevertheless, I know it's much simpler (if I knew it), much simpler than the structure of this novel or what is implied in this novel. Just a detail: the fact that the letter is burned doesn't mean that it's not a problem of language.

Miller : That's right. That's just the point, that it's efficacious, it's absolutely efficacious even though it's not read. But you're right, it's paradoxically a matter of language. They know what it says. But that's, I think, James's point: having it burned and unread in no way takes away its effectiveness. 
Derrida : That's the argument... Lacan's argument, when he says that the fact that we don't know what was in the letter meant that it was only a matter of signifying, not the signified. They knew what was in the letter, they knew without reading it, they knew what the contents were supposed to be, like in...

Miller : ... in The Wings of the Dove. Exactly.

Birus : I'd like to come back to our debate on page twelve, page thirteen. Let me say, all we debate here is just anticipated, not by Goethe, but today by Kant, I would say. Aren't we here on a ground that is conceptualized by Kant's Critique of Pure Judgment, that all aesthetic judgments are singular judgments, but that they have the claim of universality in that respect that we think all should applaud this judgment. We can (and now, your words), we can motivate our judgment. We can say, well, because it's well structured, because this and this and this, but we cannot (that's Kant's term) we cannot necessitate it, make it be necessary. So I think the ethical problem, or the political problem (as you called it), is... well, it's similar to the question Kant debates on having secondary interests in the beauty. And that would mean it is an ethical decision or a political decision to give space for aesthetical judgment and for aesthetical arguments, to choose this model and not that. Maybe there is, in democracy and in this university as a democratical institution, maybe there can be an argument that deals in that way: this is not the time to give aesthetical arguments the first place. Now we have to deal with other problems - of minorities, for example. But if you give a place, if you give space for such aesthetical judgments, I think then are we in a situation, well, we have motivated judgments, and they are unjustifiable. You cannot necessitate it. But on the other hand, it's not only ideological bias. That would be a way to necessitate your judgment, to say, well, it's because and because and because. But an aesthetical judgment has no such cause. You cannot give a reason, sufficient reason for this...

Krieger : It's exactly this point, I think: the notion in the aesthetic that there is something associated with disinterestedness. Hillis's point (representing many many other persons who today would make the same point) is that there's no such thing as a disinterested judgment. It is always the result of interest, and the interest is what he's calling ideological. And therefore he is, in effect, as many others are today, ruling out the very possibility of our being able to make an aesthetic 
judgment, or claim the kind of disinterest required in order to do it.

Birus : I understood it in a different way, in that way that the aesthetical argument hasn't, automatically and by itself, the last vote. It has to be argued. Is that, in such a curriculum or in educational programs, the highest value? And I think that has to be debated. Whence the quarrel between cultural studies and more traditional literary studies.

Krieger : The question is whether it's ruled out.

Birus : But if you accept this aesthetical space, then I think are we in a field we can debate, like yesterday, on what is of higher value, literature that can be fully translated, or literature that always recreates intranslatability? But this is an aesthetical question and, for instance Kierkegaard can say, the aesthetical stage is a minor stage compared with the ethical or the religious stage.

Krieger : The aesthetic is ideology free.

Readings : But I don't think that...

Birus : But there is an aesthetic ideology.

Krieger : Oh, yes.

Readings : If you just focus on disinterest, you miss the other side of Kant's point, which is that the singularity of the aesthetic judgment is asserted as if it were universally valid, by appeal to a sensus communis that is not anthropological or comparative or empirical in any way. That access to the possibility of universality, which functions for Kant like a kind of... almost like a pocketbook...

Krieger : But that's what makes it disinterested. That's what reconfirms the disinterest, because if it's universal enough, then all the interests cancel each other out.

Derrida : Beauty as symbol of morality, beauty as nonconceptual universality.

Krieger : Yes.

Readings : The question is, of course, whether there is such a space at the university.

Birus : Or should be. 
Miller : No, the appeal to the aesthetic, partly because of the history of what happened to that concept of the aesthetic later on in the nineteenth and twentieth century, makes me very uneasy - the appeal to the aesthetic as a bridge between the ethical and the cognitive, practical reason and pure reason. So that the sentence in Proust that follows the one I read made me very uneasy. It is a place, a characteristic place, where he's been talking about how if you were a master of psychology, and so on, you'd be able to understand politics... If you're not, you can "only make futile pronouncements." But if he is a master of the psychology of individuals, then "these colossal masses of conglomerated individuals will assume, in his eyes, as they confront one another," - and then what does he say? - "a beauty more potent than that of the struggle which arises from mere conflict between two characters." So it's a place where the political moment here, in this passage, where the political and the individual vanishes in what I would think of as the aesthetic side of Proust, a mere admiration for the beauty of mass conflict. He's talking about the First World War. The First World War is more beautiful than my troubles with Albertine because it's bigger. And not because it's more important. And that made me profoundly uneasy, that aspect of Proust... Well, it's complicated in Proust because he turned against Ruskin, as everybody knows, precisely because he saw Ruskin as an aestheticizer.

Wang : After reading your paper, I'm especially interested in what you talk about the role of the English department or the university in modern society. And I thought what you said is that literature is so complicated that it's more complicated than even what we generally call science and technology today. But then Ludwig says it's more complicated than the media, or something like that. Did you...?

Pfeiffer : That's what Jacques' point was, yes.

Wang : You mean movies?

Derrida : I was referring to the technology of the media. Not the words, not the words. Not the films, no, no, no, no.

Wang : When I was in a situation teaching at the Hong Kong University of Science and Technology, and for a whole year as the only Professor of Literature there, I had to convince my colleagues and students, all science and business majors, that literature anticipates many 
things they are or will be doing. Then, for example, I would cite Ch'ii Yuan who in his poetry flies through space. He wrote about the "experience" in the fourth century B.C, his flight to the unknown, and it's very very exciting. Then, I also realized that they could fly, but they never knew that actually some miles above the ground it was forty degrees below zero. Of course our mind for literary creation is great, but there is something else. This is almost like a challenge for myself. And with that then, there are problems in Paradise Lost, which also involves descriptions of flying down and up in the day.

Miller : Troubled by the great poem that I defend, right.

Behler : I want to respond briefly to Hendrik. I agree with you about the desirability of the aesthetic realm and the autonomy of the aesthetic, but that's precisely the issue in today's university debate, because this tradition has received a very bad name. It's considered to be a realm free of politics, and there's something...

Yu : What your model suggests does not preclude any change of the status quo. It doesn't mandate any particular change in the curriculum whatsoever, from the aesthetic to the political standards. We can just, everybody can just teach as before. Cultural studies is not going to...

Miller : That is true. It's conservative from that point of view. And obviously my strong motivation (I said that) was to feel that I can teach Proust with a clear conscience.

Yu : Right.

Miller : On the other hand, it doesn't allow me to say my colleagues cannot do what they are doing...

Yu : Absolutely.

Miller : ... which is to teach very different, non-canonical works. It doesn't give me any authority to say, "This is wrong, and we need to go back..." It doesn't really justify what our colleagues in the English Department are doing now, cleaning up the English curriculum because they consider English literature to contain values, and so on, that everybody ought to be thought.

Yu : Nor does it reformulate the canon.

Miller : No. 
Krieger : Probably You're giving them a bad rap, because in the last meeting we had a different discussion. (I don't know whether you were there or not.) Again and again and again, the phrase "English literature" was replaced by the phrase "literature in English."

Miller : Right.

Krieger : Specifically, it's to allow literature from any place that happens to use this language.

Miller : No, I would see that as a...

Miller : Proust would be a "no," but Australia...

Krieger : It was looked upon as a liberalizing. That was my point.

Miller : Right. No, no, I think that's certainly an opening up.

Iser : There is no need for a summary. Perhaps only one question remains.

Miller : Yes?

Iser : If otherness defies thematization, why do we keep naming it? Is naming a form of translatability, or better still an iteration of translatability?

Miller : It's a catachresis.

Derrida : Why do we have to stop?

Miller : We have to stop. Notice that my title is "Humanistic Discourse and the Others." There's a plural. Why is there a plural on that? It's very awkward. But it seems to me that the word "other" begs all sorts of questions, because it's almost impossible not to think of it then as somehow single, unitary. And even to personify it. So that if you use the plural (which I've tried to do, and it doesn't really work), you're trying to break that down. Because the "other," in the singular, means both at the same time the absolutely other and somehow the other person. That's Levinas' problem, "others" is a singular plural or a plural singular.

Derrida : Speaking of translation, if I may quote a sentence you quoted by me, "Tout autre est tout autre", is absolutely untranslatable, absolutely untranslatable... 
Krieger : So then translate it.

Derrida : Absolute other.

Krieger : The absolute other sounds so much like a Platonic universal, and all the others we meet, whether they be racial, ethnic, gendered, and so on and so on, sound like representations of the universal other.

Miller : That's the problem.

Accueil Surfaces | Table des matières | Recherche Surfaces Home Page | Table of Contents | Search

PUM | Livres | Revues | Publications électroniques | Vente et distribution 